\title{
Influence of the Amazon River on dissolved and intra-cellular metal concentrations in Trichodesmium colonies along the western boundary of the sub-tropical North Atlantic Ocean
}

\author{
A. Tovar-Sanchez ${ }^{1}$ and S. A. Sañudo-Wilhelmy ${ }^{2}$ \\ ${ }^{1}$ Department of Global Change Research, IMEDEA (CSIC-UIB) Instituto Mediterráneo de Estudios Avanzados, \\ Miquel Marqués 21, 07190 Esporles, Spain \\ ${ }^{2}$ University of Southern California, Department of Biological Sciences and Department of Earth Sciences, \\ 3616 Trousdale Parkway, AHF 206, Los Angeles, CA90089-0371, USA
}

Received: 18 August 2010 - Published in Biogeosciences Discuss.: 27 August 2010

Revised: 26 December 2010 - Accepted: 21 January 2011 - Published: 28 January 2011

\begin{abstract}
Despite the ecological importance of Trichodesmium spp. for the global oceanic nitrogen budget, there is limited information on their trace metal composition in field samples. We report dissolved $(<0.22 \mu \mathrm{m})$ metal concentrations measured in surface waters $(\mathrm{Ag}, \mathrm{Cd}, \mathrm{Co}, \mathrm{Cu}, \mathrm{Fe}$, $\mathrm{Mo}, \mathrm{Ni}, \mathrm{P}, \mathrm{Pb}$ and $\mathrm{V}$ ) and in the total and the intracellular pool (Ag, Al, Cd, Co, Cu, Fe, Mn, Mo, Ni, P, Pb, V) of Trichodesmium populations collected in the western subtropical North Atlantic Ocean (April-May 2003) within the influence of the Amazon River plume. Dissolved element distributions were strongly influenced by the River discharge, with concentrations of some elements varying directly (i.e. $\mathrm{Cd}$, Mo and $\mathrm{V}$ ) or inversely ( $\mathrm{Ag}, \mathrm{Co}, \mathrm{Cu}, \mathrm{Fe}, \mathrm{Ni}, \mathrm{P}$ and $\mathrm{Pb}$ ) with surface salinity. Intracellular metal values to phosphorous ratios (mol:mol) for $\mathrm{Cd}, \mathrm{Co}, \mathrm{Cu}, \mathrm{Fe}, \mathrm{Mn}, \mathrm{Mo}$, Ni and $\mathrm{V}$ ranged from $9.0 \times 10^{-6}$ for $\mathrm{Cd}$ to $4.4 \times 10^{-2}$ for Fe. Although total metal composition was significantly correlated with the intracellular content in the Trichodesmium colonies for some elements (e.g., $\mathrm{Co}, \mathrm{Cu}, \mathrm{V}$ ), metal pools in the phytoplankton did not co-vary with the dissolved metal concentrations, suggesting that water column measurements may not be good predictors of the intracellular metal concentrations. The impact of physical parameters and bioactive elements on biological processes such as nitrogen fixation, carbon drawdown and biomass production in Trichodesmium colonies was explored by using a principal component analysis test (PCA). The analysis indicated that the biological drawdown of dissolved inorganic carbon (DIC) by Trichodesmium seems to
\end{abstract}

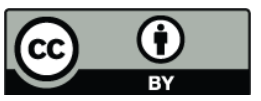

Correspondence to: A. Tovar-Sanchez (atovar@imedea.uib-csic.es) be influenced by the internal content of $\mathrm{Fe}, \mathrm{Co}, \mathrm{Cd}$, and $\mathrm{Cu}$, while nitrogen fixation seems more influenced by mixed layer depth and dissolved $\mathrm{Fe}$ and $\mathrm{Ni}$ concentrations.

\section{Introduction}

Marine cyanobacteria in the genus Trichodesmium are important $\mathrm{N}_{2}$-fixing organisms in oligotrophic tropical and subtropical oceans, playing an important role in primary production and in the new nitrogen budget (Karl et al., 1997; Capone et al., 1997; LaRoche and Breitbarth, 2005; Westberry and Siegel, 2006). Important advances have been made in understanding their geographical distribution and abundance (e.g., Carpenter et al., 2004; Westberry and Siegel, 2006), nutrient requirements (Mills et al., 2004; Tuit et al., 2004; Kustka et al., 2002; Sañudo-Wilhelmy et al., 2001) and the effect of environmental variables on bloom dynamics (Subramaniam et al., 2008; Tovar-Sanchez et al., 2006). Although recent results have shown that the Amazon River enhances diazotrophy in the tropical North Atlantic Ocean (Subramaniam et al., 2008), some critical issues still remain largely unknown, such as evaluating the impact of that River on the cycling of bioactive dissolved metals and on the intracellular metal levels in field populations of Trichodesmium. Whereas "total" metal composition (intra and extracellular pools combined) of field-collected Trichodesmium colonies have been reported in the western tropical North Atlantic (Tovar-Sanchez et al., 2006), their internal metal pool and its relation to both the Amazon River plume and bloom dynamics are still unknown. The internal metal pool represents the biological fraction (e.g., cellular quota; Hassler and

Published by Copernicus Publications on behalf of the European Geosciences Union. 


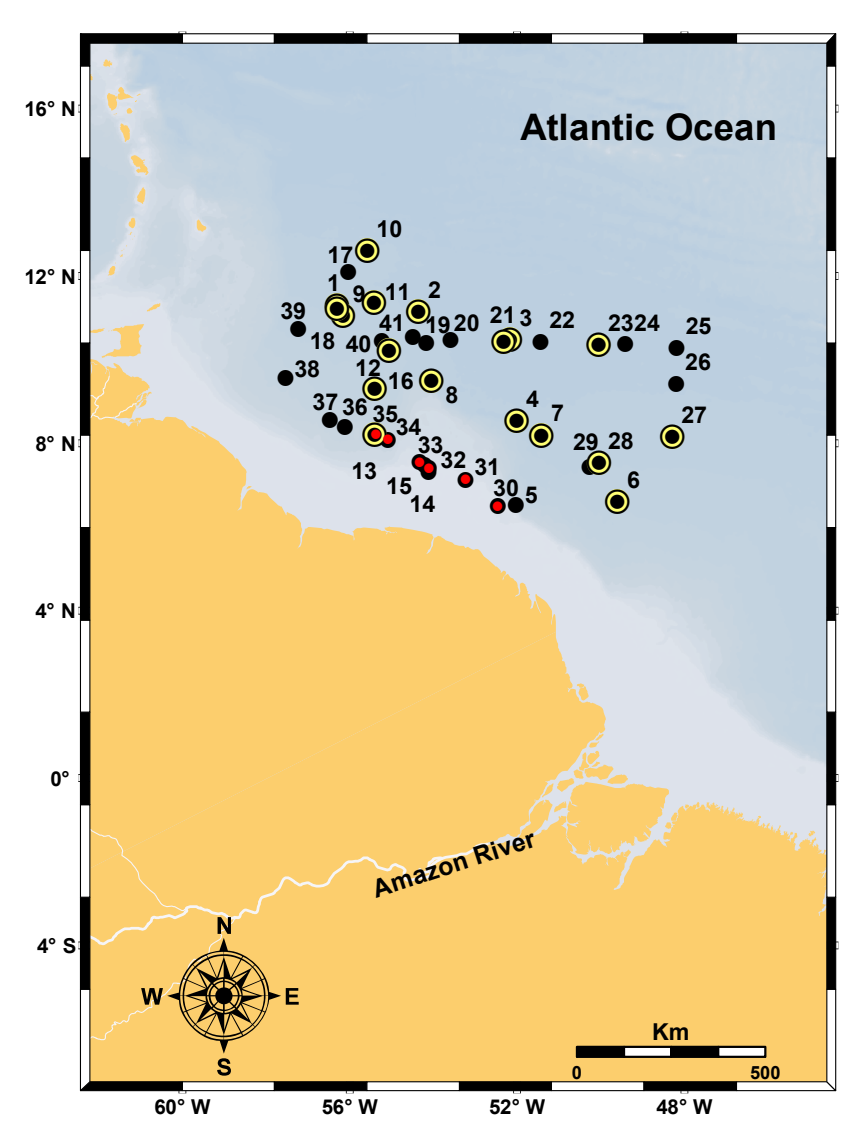

Fig. 1. Sampling location: water samples (black circles), Trichodesmium colonies (yellow circles) and 24-h tidal cycling (red circles) stations.

Schoemann, 2009; Tovar-Sanchez et al., 2003), and therefore quantification of this metal pool is important to understand the biochemical status and/or the nutritional requirements of Trichodesmium in the field. Furthermore, simultaneous measurements of bioactive trace metals in the intracellular and in the dissolved water column pools could help us to better understand the processes and mechanisms influencing the bioavailability of trace elements in the field.

In this study, we have expanded the work of TovarSanchez et al. (2006), to investigate the geographical distribution of dissolved elements in surface waters both in and out of the influence of the Amazon River plume, and the relationship of the plume with the internal metal composition of Trichodesmium. A Principal Component Analysis (PCA) was carried out to try to identify the bioactive trace elements and physical parameters (e.g., salinity, temperature, and mixed layer depth) influencing nitrogen fixation, carbon drawdown and biomass production during our study along the western boundary of the subtropical Atlantic Ocean.

\section{Methods}

\subsection{Sampling and analysis}

Sampling was carried out on board the RV Seaward Johnson II, during April-May 2003 under high riverine flow conditions (Tovar-Sanchez et al., 2006). A total of 42 locations were sampled in this study, distributed along the western tropical North Atlantic Ocean within and outside of the influence of the Amazon River (Fig. 1). Dissolved surface seawater samples were collected from a "towed fish" (Vink et al., 2000) deployed at $2 \mathrm{~m}$ below the surface and towed at about 5 knots during sampling. Seawater was pumped through acid-cleaned Teflon tubing coupled to a C-flex tubing (for the Cole-Parmer peristaltic pump head), filtered through an acid-cleaned polypropylene cartridge filter $\left(0.22 \mu \mathrm{m}\right.$, MSI, Calyx $\left.{ }^{\circledR}\right)$, and collected in a 1 L LDPE acidwashed bottle in a portable HEPA class-100 unit to avoid any contamination. Subsequent seawater sample manipulations were carried out in a class-100 trace metal laboratory on land. Seawater samples were acidified with sub-boiling quartz distilled $\mathrm{HCl}(\mathrm{Q}-\mathrm{HCl})$ to $\mathrm{pH}<1.5$ and stored for at least 1 month prior to analysis. Metal concentrations $(\mathrm{Ag}, \mathrm{Cd}, \mathrm{Co}, \mathrm{Cu}, \mathrm{Fe}, \mathrm{Mo}, \mathrm{Ni}, \mathrm{Pb}$, and $\mathrm{V})$ were determined by Inductively Coupled Plasma Mass Spectrometry (ICP-MS; ThermoFinigan, Element 2) using both external standards and an indium spike as an internal standard after pre-concentration with an ammonium1-pyrrolidinedithiocarbamate/diethylammonium diethyldithiocarbamate (APDC/DDDC) organic extraction (Bruland et al., 1985). In order to eliminate isobaric interferences, concentrations of $\mathrm{Ag}, \mathrm{Cd}, \mathrm{Mo}$ and $\mathrm{Pb}$ were determined by ICP-MS in low-resolution mode, while $\mathrm{Co}, \mathrm{Cu}, \mathrm{Fe}, \mathrm{Ni}$, and $\mathrm{V}$ were determined in medium-resolution. The extraction efficiency and accuracy of the metal determinations was obtained by the analysis of a certified standard reference material (CASS-3), with recoveries ranging from $93 \%$ for Mo to $106 \%$ for Pb. Dissolved phosphorous concentrations were determined using the MAGIC method (Karl and Tien, 1992). Detection limits, calculated as three times the standard deviation of the analytical blanks were 1.5, 1.6, 8.0, 39.8, 54.9, 30.3, 779.1, 8.4 and 6.9 for $\mathrm{Ag}, \mathrm{Cd}, \mathrm{Co}, \mathrm{Cu}, \mathrm{Fe}, \mathrm{Mo}, \mathrm{Ni}, \mathrm{Pb}$ and $\mathrm{V}$ respectively (all in $\mathrm{pM}$ ). Trichodesmium colonies were collected at a depth of $\sim 5 \mathrm{~m}$ using an acid-cleaned all-plastic 100-micron mesh plankton net. Individual colonies were removed from the acid-cleaned polyethylene net collector with a plastic inoculating loop under a microscope in a class-100 laminar flow hood. We recognize that this type of sampling does not exclude bacteria that could be attached to the Trichodesmium colonies. At each station, 70 to 130 colonies were manually collected for both intracellular and total metal measurements (Table S1 in the Supplement). For the quantification of total metal concentrations, colonies were stored frozen in Teflon vials until acid digestion. Samples were digested in Teflon digestion vials using a 


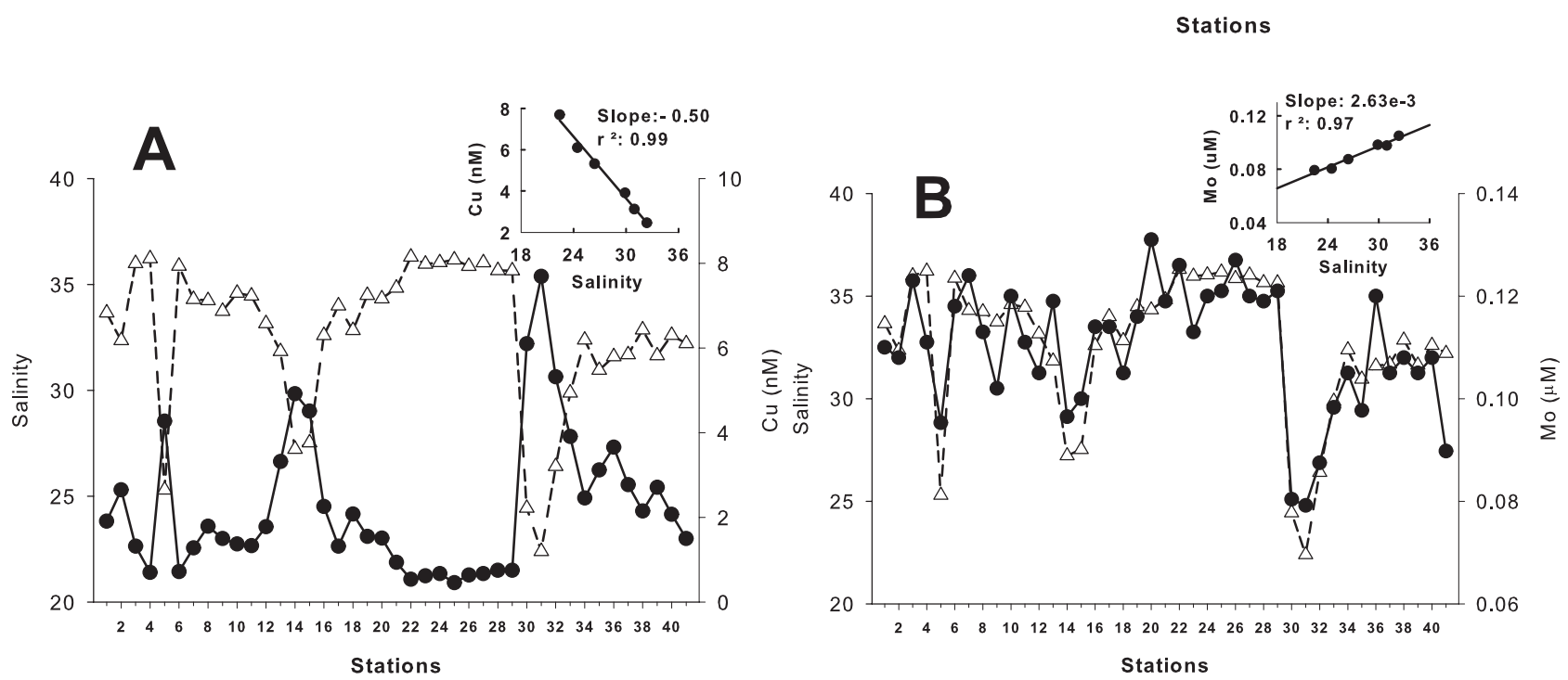

Fig. 2. Geographical distribution of surface salinity (triangles), dissolved $\mathrm{Cu}$ (panel (a) - filled circles) and Mo (panel (b) - filled circles) measured in the western boundary of the subtropical North Atlantic Ocean. The insets represent linear regressions of the dissolved elements plotted against salinity for six different sampling times over a 24 -h period.

combination of Q- $\mathrm{HNO}_{3}(60 \%), \mathrm{Q}-\mathrm{HCl}(30 \%)$ and Q-HF $(10 \%)$ acids, and heated on a hot plate until complete digestion (Sañudo-Wilhelmy et al., 2001, 2004). Metal concentrations ( $\mathrm{Ag}, \mathrm{Cd}, \mathrm{Co}, \mathrm{Cu}, \mathrm{Fe}, \mathrm{Mn}, \mathrm{Mo}, \mathrm{Ni}, \mathrm{P}$ and $\mathrm{V}$ ) were determined by ICP-MS in the acid-digests. Intracellular metal levels were determined after washing a sub-sample of the field-collected Trichodesmium colonies with the oxalate reagent described by Tovar-Sanchez et al. (2003). It is still unclear whether this chemical treatment removes any surfaced-attached bacteria. Procedural blanks for total and intracellular metal determination were obtained by applying the protocols described above without including the field colonies. All of the biological data (i.e., nitrogen fixation, biological drawdown of DIC and chlorophyll-a) as well as mixed-layer depth measured during our sampling campaign were previously reported by Subramaniam et al. (2008).

\section{Results and discussion}

\subsection{Dissolved trace metal distributions}

Dissolved metal (Ag, Cd, Co, Cu, Fe, Mo, Ni, Pb, V) and P concentrations measured in surface waters during our study are reported in Table S1 in the Supplement. The impact of the Amazon River plume on the chemical composition of our sampling locations is reflected in the salinity gradient (22.4-36.3) as well as in the dissolved trace element distributions (Table S1). The influence of the river plume on metal distributions was different for different metals. For example, the spatial gradient in dissolved $\mathrm{Ag}, \mathrm{Cu}, \mathrm{Fe}, \mathrm{Ni}$, $\mathrm{Pb}$, and $\mathrm{P}$ (range of concentrations from low to high salinity:
$\mathrm{Ag}, 15.50-8.43 \mathrm{pM}$; $\mathrm{Cu}, 7.69-0.46 \mathrm{nM} ; \mathrm{Fe}, 8.70-0.41 \mathrm{nM}$; $\mathrm{Ni}, 1.93-0.88 \mathrm{nM}$; Pb, 77.77-10.09 pM; P, 33.72-2.31 nM) varied inversely with salinity (Figs. $2 \mathrm{a}$ and S1A-F in the Supplement), suggesting that the Amazon River plume was the main source of these elements to the area of study during our sampling. A weaker trend with salinity was observed for dissolved Co (range: 172.7-17.32 pM; Fig. S1E); the distribution of this element in estuaries is influenced by desorption from suspended particles and surficial sediments (TovarSanchez et al., 2004).

In contrast, the spatial distribution of dissolved $\mathrm{Cd}$, Mo and $\mathrm{V}$ (range from low to high salinity: $\mathrm{Cd}, 0.31-0.53 \mathrm{nM}$; Mo, $0.08-0.13 \mu \mathrm{M} ; \mathrm{V}, 20.92-35.69 \mathrm{nM}$ ) varied directly with salinity, suggesting that the Amazon River plume is not the source of these elements, but rather the river input diluted their concentration in the Ocean (Figs. 2b and S1G-H in the Supplement).

To further establish the impact of the Amazon River plume on trace element distributions in our area of study, we collected water samples at 6 stations located in and out of the plume in a $24 \mathrm{~h}$ period (salinity range: $22.4-30.9$; stations 30-35 in Table S1). The positive or negative slopes obtained for different elements in the linear regression analysis with salinity confirms our results regarding the variable influence of the river on metal concentrations discussed above (insets in Figs. 2 and S1 in the Supplement). Although our data is limited, we used those metal-salinity linear regressions to obtain a first-order approximation of the "hypothetical" metal concentrations at the low-salinity end-member of the Amazon River basin that would explain the concentrations measured at the seawater end member, assuming conservative 
Table 1. Hypothetical end-member metal concentrations in the upper Amazon River Basin. Values are compared with concentrations reported in the upper Amazon River Basin by Seyler and Boaventura (2003). n.r.: not reported.

\begin{tabular}{lccc|cc}
\hline & $\begin{array}{c}\text { Extrapolated } \\
\text { concentration } \\
\text { to zero salinity }\end{array}$ & \multicolumn{2}{c|}{ Solimões } & \multicolumn{2}{c}{ Amazonas } \\
& & & Nov 1995 & May 1997 \\
\hline $\mathrm{Mo}(\mathrm{nM})$ & 18.1 & $4.1 \pm 1.4$ & $3.2 \pm 1.3$ & $3.2 \pm 0.42$ & $1.7 \pm 0.33$ \\
$\mathrm{Ag}(\mathrm{pM})$ & 30.5 & n.r. & n.r. & n.r. & n.r. \\
$\mathrm{Cd}(\mathrm{nM})$ & 0.04 & $0.1 \pm 0.04$ & $1.0 \pm 0.34$ & $0.1 \pm 0.01$ & $1.4 \pm 0.38$ \\
$\mathrm{~Pb}(\mathrm{pM})$ & 213.6 & n.r. & n.r. & n.r. & n.r. \\
$\mathrm{V}(\mathrm{nM})$ & 8.7 & $34.5 \pm 9.3$ & $21.7 \pm 6.2$ & $20.2 \pm 1.5$ & $13.0 \pm 0.72$ \\
$\mathrm{Fe}(\mathrm{nM})$ & 24.8 & n.r. & n.r. & n.r. & n.r. \\
$\mathrm{Ni}(\mathrm{nM})$ & 2.6 & $3.0 \pm 0.35$ & $15.8 \pm 2.5$ & 2.0 & $14.6 \pm 4.5$ \\
$\mathrm{Cu}(\mathrm{nM})$ & 18.6 & $22.6 \pm 2.9$ & $25 \pm 2.3$ & $19.2 \pm 0.45$ & $21.1 \pm 5.4$ \\
\hline
\end{tabular}

estuarine mixing (Table 1). Predicted metal concentrations at low salinities for $\mathrm{Cd}, \mathrm{Cu}$ and $\mathrm{Ni}$ were in excellent agreement with the concentrations measured by Seyler and Boaventura (2003) in the upper Amazon River basin (Table 1). However, our calculated concentrations tend to underestimate $\mathrm{V}$ and overestimate Mo concentrations measured in the upper river basin. While the reasons for these discrepancies are unclear, we believe that they are not totally unexpected taking into consideration the length of the river from the low salinity region to the river mouth (about $2000 \mathrm{~km}$ ), the high diversity of geomorphological formations along the course of the river and the large number of tributaries discharging into the Amazon river mainstream (Seyler and Boaventura, 2003).

\subsection{Trace element composition in Trichodesmium colonies}

In order to investigate the influence of dissolved metal concentrations on the elemental composition in Trichodesmium colonies, we analyzed two different metal pools, intracellular and surface-scavenged, in the colonies collected at the western tropical North Atlantic Ocean (Fig. 1). Total (intracellular + surface-scavenged; $\mathrm{Ag}, \mathrm{Al}, \mathrm{Cd}, \mathrm{Co}, \mathrm{Cu}, \mathrm{Fe}, \mathrm{Mn}, \mathrm{Mo}$, $\mathrm{Ni}, \mathrm{P}, \mathrm{Pb}, \mathrm{V})$ and intracellular metal $(\mathrm{Cd}, \mathrm{Co}, \mathrm{Cu}, \mathrm{Fe}, \mathrm{Mn}$, $\mathrm{Mo}, \mathrm{Ni}, \mathrm{P}, \mathrm{V}$ ) concentrations measured in those colonies are reported in Table S1.

Element abundances in the intracellular fraction ranged from $0.49 \pm 0.27 \mathrm{~mol}$ per colony for $\mathrm{P}$ to undetectable levels for $\mathrm{Pb}(\mathrm{P}>\mathrm{Fe}>\mathrm{V}>\mathrm{Ni}>\mathrm{Mo}>\mathrm{Zn}>\mathrm{Cu}>\mathrm{Mn}>\mathrm{Co}>\mathrm{Cd}>\mathrm{Pb})$ (Table S1). The general concentration pattern seems to be consistent with the metabolic requirements of Trichodesmium. For example, $\mathrm{P}$ and $\mathrm{Fe}$ are well known essential nutrients and considered limiting elements for $\mathrm{N}_{2}$ fixation, oceanic primary production and carbon dioxide sequestration (Sañudo-Wilhelmy et al., 2001; Mills et al., 2004). The high internal content of $\mathrm{Fe}$ and Mo in the colonies is consistent with the requirements for these elements by the nitrogenase enzyme for nitrogen fixation (Tuit et al., 2004), and for other Fe proteins involved in aerobic nitrogen fixation in Trichodesmium spp. (Zehr et al., 1997).

Explanations for the high internal concentrations of $\mathrm{Ni}$ and $\mathrm{V}$ are not as obvious. In the case of $\mathrm{Ni}$, recent research indicates that $\mathrm{Ni}$ can be a limiting factor for nitrogen fixation by Trichodesmium in oceanic regions ( $\mathrm{Ho}$ and $\mathrm{Hu}, 2010)$. This could be associated with the synthesis of $\mathrm{Ni}$-superoxide dismutase and Ni-containing urease by Trichodesmium, as previously shown in other marine cyanobacteria (Dupont et al., 2008). Furthermore, $\mathrm{N}_{2}$-fixing cyanobacteria also posses genes encoding a Ni-Fe hydrogenase (Seabra et al., 2009). Only two biological roles for $\mathrm{V}$ have been identified - as cofactors in V-nitrogenases and V-haloperoxidases (VHPOs; Rehder, 2008). To date, no marine cyanobacteria are known to possess V-nitrogenases (Walmsley and Kennedy, 1991; Stal and Zehr, 2008). Though VHPO activity has so far only been observed in eukaryotes (Winter and Moore, 2009), several cyanobacterial genomes (e.g. Synechoccus sp. CC931, Acaryochloris marina MBIC11017) possess genes annotated in the IMG database as likely VHPOs, with high sequence homology to characterized eukaryotic VHPOs (http://img. jgi.doe.gov). A number of other cyanobacteria, including the published Trichodesmium genome, contain an uncharacterized enzyme annotated as VHPO/acid phosphatase-related with predicted peroxidase function. It is possible that the high $\mathrm{V}$ quotas measured in this study are due to usage as a cofactor in this uncharacterized enzyme. Vanadate and phosphate are also chemical analogs, which suggests that $\mathrm{V}$ incorporation could happen as part of phosphate uptake (Ray et al., 1993).

In order to provide a comparison of the metal concentrations measured in the colonies independent of cell volume, all of the Trichodesmium metal data was normalized to the amount of phosphorous (mol:mol). The normalized (total, intra and extracellular) pools were calculated as follow: 


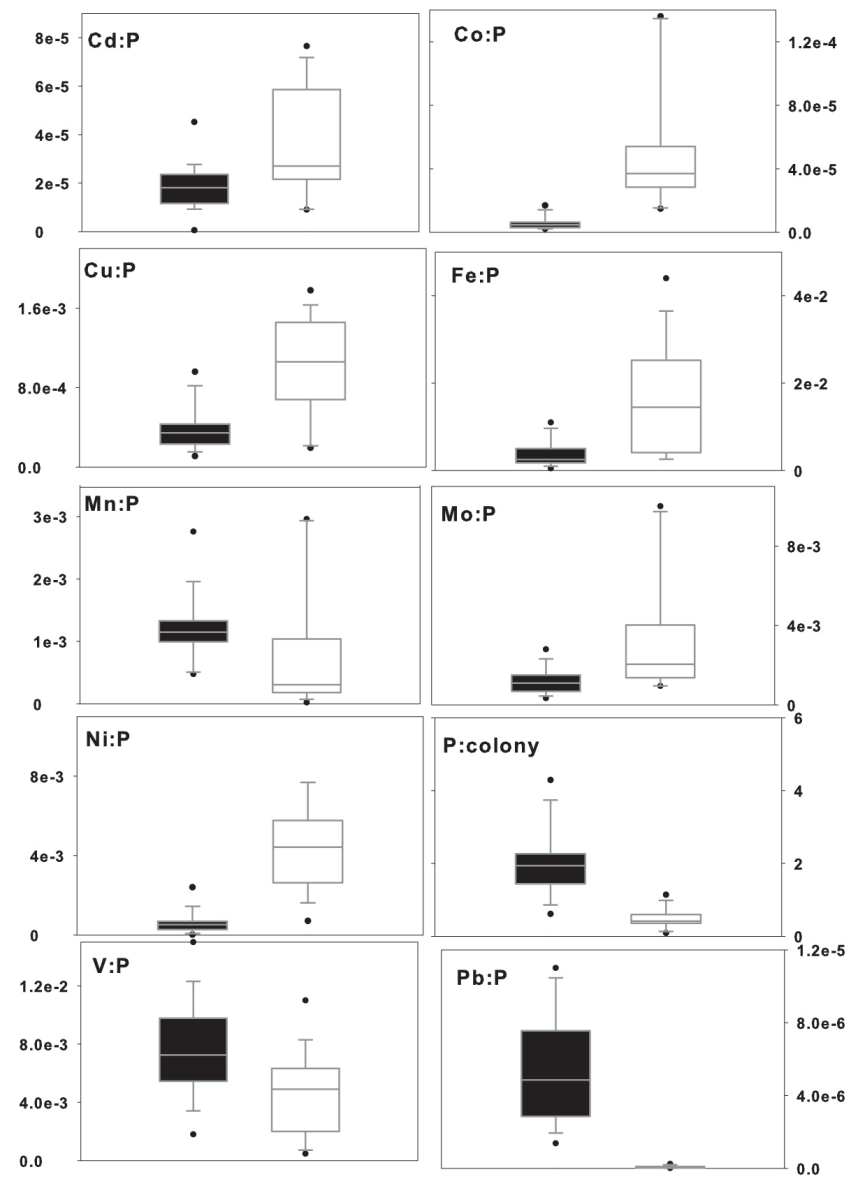

Fig. 3. Box-plots representing the scavenged (filled boxes) and intracellular (open boxes) metal pools measured in field populations of Trichodesmium (all of them in mol:mol, with exception of $\mathrm{P}$ that is reported as nmol per colony). The solid line represents the median, the dimensions of the box delineates the 25th and 75th percentile confidence intervals and the error bars show the 10th and 90th percentile confidence intervals.

$$
\begin{aligned}
& (\mathrm{Me}: \mathrm{P})_{\text {total }}=\mathrm{Me}_{\text {total }}: \mathrm{P}_{\text {total }} \\
& (\mathrm{Me}: \mathrm{P})_{\text {intracellular }}=\mathrm{Me}_{\text {intra }}: \mathrm{P}_{\text {intra }} \\
& (\mathrm{Me}: \mathrm{P})_{\text {extracellular }}=\left(\mathrm{Me}_{\text {total }}-\mathrm{Me}_{\text {intracellular }}\right) / \\
& \left(\mathrm{P}_{\text {total }}-\mathrm{P}_{\text {intracellular }}\right)
\end{aligned}
$$

where "total" refers to the elemental composition measured in the colonies after the acid-digestion and "intracellular" is the elemental composition obtained after applying the oxalate wash (see Methods).

Averages of intracellular metal:P were $3.5 \times 10^{-5}, 4.7 \times$ $10^{-5}, 7.4 \times 10^{-4}, 9.9 \times 10^{-4}, 3.2 \times 10^{-3}, 4.5 \times 10^{-3}, 4.5 \times$ $10^{-3}$ and $1.5 \times 10^{-2}$, for $\mathrm{Cd}, \mathrm{Co}, \mathrm{Mn}, \mathrm{Cu}, \mathrm{Mo}, \mathrm{V}, \mathrm{Ni}$ and Fe, respectively (Table S1 and Fig. 3). While these intracellular contents probably denote the biological requirements for these metals, others elements like Mn was mostly found
Table 2. Range of values for metal concentrations normalized to $\mathrm{P}$, measured in field colonies of Trichodesmium in this study and those reported for other species of phytoplankton. The units are $\mathrm{mmol} \mathrm{mol}{ }^{-1}$, except for Cd:P given in $\mu \mathrm{mol} \mathrm{mol}^{-1}$. n.r.: not reported.

\begin{tabular}{lccl}
\hline & ${ }^{1}$ Trichodesmium & ${ }^{2}$ T. weissflogii & ${ }^{3}$ Ethmodiscus \\
\hline Cd:P & $9.0-76.5$ & $6.6-8.3$ & n.r. \\
Co:P & $0.01-0.14$ & $0.07-0.08$ & n.r. \\
Cu:P & $0.19-1.78$ & $0.08-0.09$ & n.r. \\
Fe:P & $3.0-44$ & $4.4-43.6$ & 6.5 \\
Mn:P & $0.02-2.96$ & $3.1-4.1$ & n.r. \\
Mo:P & $1.0-10.2$ & n.r. & n.r. \\
Ni:P & $0.7-11.2$ & n.r. & n.r. \\
V:P & $5.0-11.4$ & $0.018-0.02$ & n.r. \\
\hline
\end{tabular}

1 this work; ${ }^{2}$ Tang and Morel (2006); ${ }^{3}$ Villareal et al. (2007)

on the cell surface ( $\sim 74 \%$ surface scavenged; Fig. 3$)$, suggestive of a lower cellular demand or lower bioaccumulation rates (Tang and Morel, 2006; Whitfield, 2001). However, we should point out that intracellular metal concentrations are also influenced by "luxury" uptake (Sunda and Huntsman, 1995, 1997) and therefore, we cannot fully establish that those metal concentrations represent their actual biological demand in the field. However, the range of intracellular metal concentrations measured in the Trichodesmium colonies were in agreement with the metal:P range reported for other phytoplankton species (i.e. diatoms Thalassiosira weissflogii and Ethmodiscus rex and gazellae), grown under laboratory conditions (Table 2), suggesting similar metal requirements among different marine phytoplankton species. The exceptions were $\mathrm{Co}$ and $\mathrm{V}$ whose concentrations in Trichodesmium (Co, range: $0.01-0.14 \mathrm{mmol} \mathrm{mol}^{-1}$; $\mathrm{V}$, range: $5.0-11.4 \mathrm{mmol} \mathrm{mol}^{-1}$ ) were one and two orders of magnitude higher than in T. weissflogii (Co, range: $0.07-$ $0.08 \mathrm{mmol} \mathrm{mol}^{-1}$; $\mathrm{V}$, range: $0.018-0.02 \mathrm{mmol} \mathrm{mol}^{-1}$, respectively; Table 2). As previously suggested, metal content of field populations of phytoplankton seems to be more variable than those reported in laboratory culture studies (e.g., Tovar-Sanchez et al., 2006).

We found significant linear correlations between the intracellular and the total fraction for many elements measured in the colonies along the spatial gradient of dissolved metal concentrations (Fig. $4 \mathrm{a}-\mathrm{g}$ ). The best linear correlations were for $\mathrm{Co}\left(r^{2}=0.69, p<0.001\right), \mathrm{Cu}\left(r^{2}=0.58, p<0.001\right)$, $\mathrm{V}\left(r^{2}=0.56, p<0.001\right), \mathrm{Cd}\left(r^{2}=0.51, p=0.001\right)$ and Mo $\left(r^{2}=0.37, p=0.008\right)$. Despite the significant correlations between intracellular and total metal pools in the field colonies, prediction of the intracellular pool using the total metal content produced inaccurate results. Those correlations accounted, at the most, for $59 \%$ of the measured intracellular $\mathrm{Cu}$ (even lower for the rest of the metals; $\mathrm{Cd}$, $17 \%$; Co, 33\%; Fe, 21\%; Mo, 18\%; Ni, $47 \%$ and V, 33\%). 

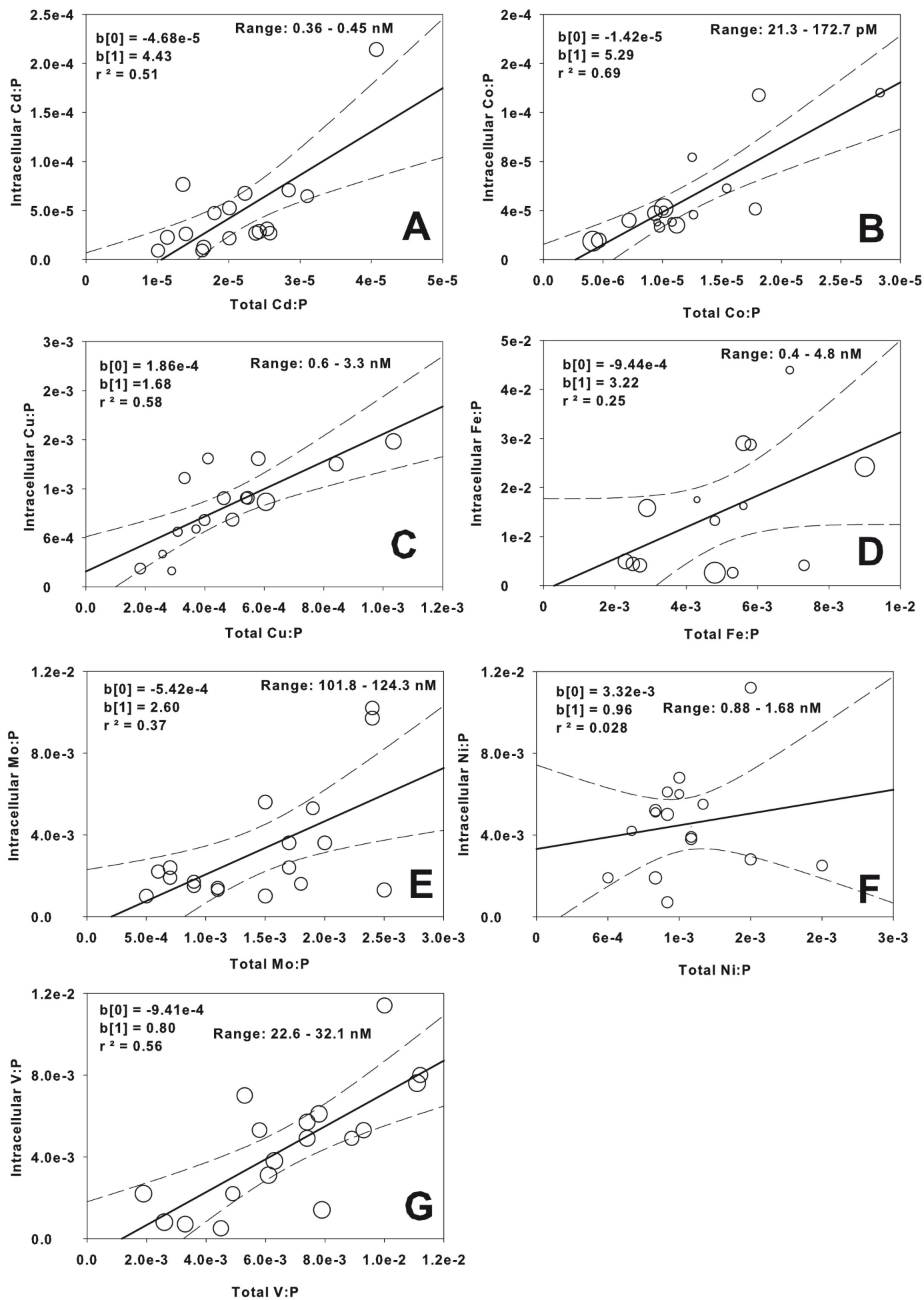

Fig. 4. Bubble plots showing the relationship between total and intracellular metal composition measured in the field colonies of Trichodesmium (all metal data normalized to P). The size of the open circles is proportional to the dissolved metal concentrations measured in surface waters where the colonies were collected. The solid line represents the linear regressions obtained among the two biological metal pools and the dashed lines are the 95th confidence limits. The range of dissolved metal levels measured during our study is also shown in each panel. 
With the exception of $\mathrm{Cu}$, for which concentrations in the colonies seems to increase as water column levels increased, in general, trace element concentrations measured in the Trichodesmium colonies did not show a clear trend with the dissolved concentrations. These results suggest that the dissolved metal fraction was not a good predictor of the metal trends observed in the colonies (Fig. 4). This is not unexpected, as the total dissolved pool includes biologically unavailable metals.

We used a Principal Component Analysis (PCA) to try to indirectly determine whether biological processes such as nitrogen fixation, carbon drawdown and biomass production (measured as chlorophyll- $a$ ) were influenced by trace elements as well as by other physical variables such as salinity, temperature, and mixed layer depth (Fig. 5; Table 2 in the Supplement). In our PCA, $69 \%$ of total variance was explained by the first two principal components ( $46 \%$ and $23 \%$ of the variance explained by the first and second factors, respectively). A graph of the principal component loadings of the first PC (Fig. 5) separates a group of parameters to the right top quadrant of the loading plot clustering biomass (as chlorophyll- $a$ ), biological drawdown of dissolved inorganic carbon (DIC) and the internal content of $\mathrm{Fe}, \mathrm{Co}, \mathrm{Cd}$, and $\mathrm{Cu}$ in Trichodesmium. Those variables are placed far from the origin of the first PC and close together suggesting that they are positively correlated. The relationship of DIC with $\mathrm{Fe}$ is in agreement with the use of that element by different enzymes for carbon fixation (Webb et al., 2001; Küpper et al., 2008; Tchernov and Lipschultz, 2008). Copper is required by cytochrome oxidase, which has been suggested to play a role in nitrogenase protection in Trichodesmium spp. (Bergman et al., 1993). Cobalt is required for the synthesis of vitamin $B_{12}$, and recent work has shown that diazotrophs seem to be among the major producers of this organic growth factor in oligotrophic waters (Bonnet et al., 2010). The inclusion of $\mathrm{Cd}$ in this first factor is unclear, as this element is not known to be involved in any enzymatic process in Trichodesmium. The variables characterizing $\mathrm{PC} 2$ are placed on the top left quadrant of the loading plot (Fig. 5) and include nitrogen fixation, mixed layer depth and some dissolved trace metals ( $\mathrm{Ni}$ and $\mathrm{Fe}$ ). This suggest that during our sampling, nitrogen fixation was mostly influenced by mixed layer depth, instead of intracellular trace elements, as those parameters cluster mostly in the first PC with biomass and biological carbon draw-down. Sañudo-Wilhelmy et al. (2001) also reported that MLD was a major factor controlling nitrogen fixation in the subtropical Atlantic. While the impact of dissolved $\mathrm{Fe}$ on nitrogen fixation is not unexpected (Mills et al., 2004), Ho and $\mathrm{Hu}$ (2010) have recently reported that, under low environmental Ni concentrations, growth of Trichodesmium may be strongly limited. The minimum intracellular Ni to achieve maximum growth rate has been estimated at about $5.0 \mathrm{mmol}$ per mol of $\mathrm{P}$ ( $\mathrm{Ho}$ and $\mathrm{Hu}, 2010)$, which is within the intracellular range quotes obtained in this study (from 0.7 to $11.2 \mathrm{mmol} \mathrm{mol}^{-1}$ to P; Table S1). Other

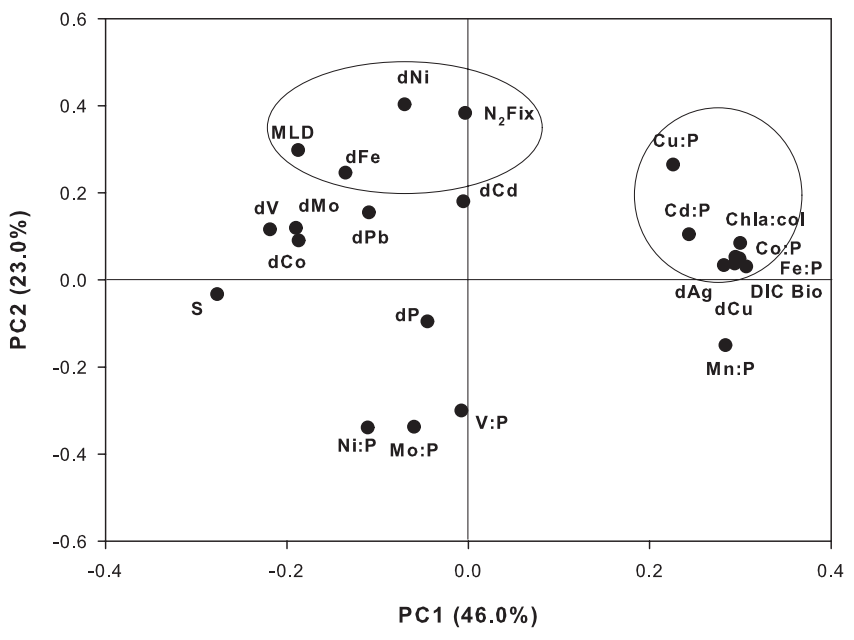

Fig. 5. Principal component analysis results. Dissolved elements: $\mathrm{dAg}, \mathrm{dCd}, \mathrm{dCo}, \mathrm{dCu}, \mathrm{dFe}, \mathrm{dMo}, \mathrm{dNi}, \mathrm{dP}, \mathrm{dPb}$ and $\mathrm{dV}$; salinity: $\mathrm{S}$; nitrogen fixation: $\mathrm{N}_{2}$ Fix; mixed layer depth: MLD; biological drawdown of DIC: DIC Bio; chlorophyll per colony: Chl- $a$ :col; intracellular metal composition of Thrichodesmium: Cd:P, Chl- $a: \mathrm{P}$, Co:P, Cu:P, Fe:P, Mn:P, Mo:P, Ni:P, and V:P. The first (PC1) and second (PC2) principal components account for $46 \%$ and $23 \%$ of the variance, respectively.

dissolved metals (e.g., $\mathrm{Co}, \mathrm{Mo}, \mathrm{Pb}, \mathrm{V}$ ) also clustered in the PC2 with MLD and very close to salinity (Fig. 5), suggesting the influence of the Amazon River and MLD on the dissolved fraction of those trace metals. Finally, intracellular V and $\mathrm{Ni}$ are important for the PC3, explaining only $17 \%$ of the variance (Table S2).

In summary, our results show that dissolved trace elements in the Western Tropical North Atlantic are strongly influenced by the Amazon River. The concentrations of dissolved $\mathrm{Cd}, \mathrm{Ni}$ and $\mathrm{V}$ appear to have a conservative behavior relative to simple mixing of freshwater and seawater, while Mo and $\mathrm{Cu}$ behave non-conservatively. Analysis of total and intracellular metal composition in Trichodesmium colonies revealed positive correlations between the two pools and weak predictive ability from total to intracellular levels. While the extracellular fraction results from a scavenging process, the internal content seems to follow biological requirements of the cyanobacteria. With the exception of $\mathrm{Cu}$, metal content in Trichodesmium colonies does not reflect the water column concentration. The PCA analysis indicates that while chlorophyll- $a$ concentration and the biological drawdown of dissolved inorganic carbon (DIC) by Trichodesmium are related to the internal content of $\mathrm{Fe}, \mathrm{Co}, \mathrm{Cd}$, and $\mathrm{Cu}$, nitrogen fixation seems to be influenced mostly by mixed layer depth and dissolved $\mathrm{Fe}$ and $\mathrm{Ni}$. 


\section{Supplementary material related to this article is available online at: http://www.biogeosciences.net/8/217/2011/ bg-8-217-2011-supplement.pdf.}

Acknowledgements. Grant support was provided by NOAA Carbon Sequestration Program (NA04OAR4310097) and US National Science Foundation grants (OCE-0962209 and OCE 0850730) to S. A. Sañudo-Wilhelmy.

Edited by: G. Herndl

\section{References}

Bergman, B., Siddiqui, P. J. A., Carpenter, E. J., and Peschek, G. A.: Cytochrome Oxidase: Subcellular Distribution and Relationship to Nitrogenase Expression in the Nonheterocystous Marine Cyanobacterium Trichodesmium thiebautii, Appl. Environ. Microb., 3239-3244, 1993.

Bonnet, S., Webb, E. A., Panzeca, C., Karl, D. M., Capone, D., and Sañudo-Wilhelmy, S. A.: Vitamin B12 excretion by cultures of the marine cyanobacteria Crocosphaera and Synechococcus, Limnol. Oceanogr., 55(5), 1959-1964, 2010.

Bruland, K. W., Coale, K. H., and Mart, L.: Analysis of seawater for dissolved cadmium, copper, and lead: an intercomparison of voltametric and atomic adsorption methods, Mar. Chem., 17, 285-300, 1985.

Capone, D. G., Zehr, J., Paerl, H., Bergman, B., and Carpenter, E. J.: Trichodesmium: a globally significant marine cyanobacterium, Science, 276, 1221-1229, 1997.

Carpenter, E. J., Subramaniam, A., and Capone, D. G.: Biomass and primary productivity of the cyanobacterium Trichodesmium spp. in the tropical N Atlantic ocean, Deep-Sea Res. Pt. I, 51, 173-203, 2004.

Dupont, C. L., Barbeau, K., and Palenik, B.: Ni Uptake and Limitation in Marine Synechococcus Strains, Appl. Environ. Microb., 23-31, 2008.

Hassler, C. S. and Schoemann, V.: Discriminating between intraand extracellular metals using chemical extractions: an update on the case of iron, Limnol. Oceanogr.-Meth., 7, 479-489, 2009.

Ho, T. and Hu, C.: Nickel Limitation of Nitrogen Fixation by Trichodesmium, Oceans Sciences Meeting, 22-26 February 2010, Portland, Oregon, USA, 2010.

Karl, D. M. and Tien, G.: MAGIC: a sensitive and precise method for measuring dissolved phosphorus in aquatic environments, Limnol. Oceanogr., 37, 105-116, 1992.

Karl, D., Letelier, R., Tupas, L., Dore, J., Christian, J., and Hebel, D.: The role of nitrogen fixation in biogeochemical cycling in the subtropical North Pacific Ocean, Nature, 388, 533-538, 1997.

Küpper, H., Šetlík, I., Seibert, S., Prášil, O., Šetlikova, E., Strittmatter, M., Levitan, O., Lohscheider, J., Adamska, I., and BermanFrank, I.: Iron limitation in the marine cyanobacterium Trichodesmium reveals new insights into regulation of photosynthesis and nitrogen fixation, New Phytol., 179, 784-798, 2008.

Kustka, A., Carpenter, E. J., and Sañudo-Wilhelmy, S. A.: Iron and marine nitrogen fixation: progress and future directions, Res. Microbiol., 153, 255-262, 2002.
LaRoche, J. and Breitbarth, E.: Importance of the diazotrophs as a source of new nitrogen in the ocean, J. Sea Res., 53, 67-91, 2005.

Mills, M. M., Ridame, C., Davey, M., La Roche, J., and Geider, R. J.: Iron and phosphorus co-limit nitrogen fixation in the eastern tropical North Atlantic, Nature, 429, 292-294, 2004.

Ray, W. J., Burgner, J. W., Deng, H., and Callender, R.: Internal Chemical Bonding in Solutions of Simple Phosphates and Vanadates, Biochemistry, 32, 12977-12983, 1993.

Rehder, D.: Bioinorganic Vanadium Chemistry, 1st edn., Wiley, Chichester, 2008.

Seyler, P. T. and Boaventura, G. R.: Distribution and partition of trace metals in the Amazon basin, Hydrol. Process., 17, 13451361, 2003.

Sañudo-Wilhelmy, S. A., Kustka, A. B., Gobler, C. J., Hutchins, D. A., Yang, M., Lwiza, K., Burns, J., Capone, D. G., Raven, J. A., and Carpenter, E. J.: Phosphorous limitation on nitrogen fixation by Trichodesmium in the central Atlantic Ocean, Nature, 411, 66-69, 2001

Sañudo-Wilhelmy, S. A., Tovar-Sanchez, A., Fu, F.-X., Capone, D. G., Carpenter, E. J., and Hutchins, D. A.: The impact of surfaceadsorbed phosphorous on phytoplankton Redfield stoichometry, Nature, 432, 897-899, 2004.

Seabra, R., Santos, A., Pereira, S., Moradas-Ferreira, P., and Tamagnini, P.: Immunolocalization of the uptake hydrogenase in themarine cyanobacterium Lyngbya majuscula CCAP1446/4 and two Nostoc strains, FEMS Microbiol. Lett., 292, 57-62, 2009.

Stal, L. J. and Zehr, J. P.: Cyanobacterial nitrogen fixation in the ocean, Diversity, regulation and ecology, in: Cyanobacteria: Molecular Biology, Genomics and Evolution, edited by: Herrero, A. and Flores, E., Horizon Scientific Press, 2008.

Subramaniam, A., Yager, P. L., Carpenter, E. J., Mahaffey, C., Björkman, K., Cooley, S., Kustka, A. B., Montoya, J. P., SañudoWilhelmy, S. A., Shipe, R., and Capone, D. G.: Amazon River enhances diazotrophy and carbon sequestration in the tropical North Atlantic Ocean, PNAS, 105(30), 10460-10465, 2008.

Sunda, W. G. and Huntsman, S. A.: Iron uptake and growth limitation in oceanic and coastal phytoplankton, Mar. Chem., 50, 189-206, 1995.

Sunda, W. G. and Huntsman, S. A.: Interrelated influence of iron, light and cell size on marine phytoplankton growth, Nature, 390, 389-392, 1997.

Tang, D. and Morel, F. M. M.: Distinguishing between cellular and Fe-oxide-associated trace elements in phytoplankton, Mar. Chem., 98, 18-30, 2006.

Tchernov, D. and Lipschultz, F.: Carbon isotopic composition of Trichodesmium spp. colonies off Bermuda: effects of colony mass and season, J. Plankton Res., 30, 21-31, 2008.

Tovar-Sanchez, A., Sañudo-Wilhelmy, S. A., Garcia-Vargas, M., Weaver, R. S., Popels, L. C., and Hutchins, D. A.: A trace metal clean reagent to remove surface-bound Fe from marine phytoplankton, Mar. Chem., 82, 91-99, 2003.

Tovar-Sanchez, A., Sañudo-Wilhelmy, S. A., and Flegal, R. A.: Temporal and spatial variations in the biogeochemical cycling of cobalt in two urban estuaries: Hudson River Estuary and San Francisco Bay, Estuar. Coast. Shelf S., 60, 717-728, 2004.

Tovar-Sanchez, A., Sañudo-Wilhelmy, S. A., Kustka, A. B., Agustí, S., Dachs, J., Hutchins, D. A., Capone, D. G., and Duarte, C. M.: Effects of dust deposition and river discharges on trace metal 
composition of Trichodesmium Spp. in the Tropical and Subtropical North Atlantic Ocean, Limnol. Oceanogr., 51(4), 17551761, 2006.

Tuit, C., Waterbury, J., and Ravizzaz, G.: Diel variation of molybdenum and iron in marine diazotrophiccyanobacteria, Limnol. Oceanogr., 49, 978-990, 2004.

Villareal, T. A., McKay, R. M. L., Al-Rshaidat, M. M. D., Boyanapalli, R., and Sherrell, R. M.: Compositional and fluorescence characteristics of the giant diatom Ethmodiscus along a $3000 \mathrm{~km}$ transect $\left(28^{\circ} \mathrm{N}\right)$ in the central North Pacific gyre, Deep-Sea Res. Pt. I, 54, 1273-1288, 2007.

Vink, S., Boyle, E. A., Measures, C. I., and Yuan, J.: Automated high resolution determination of the trace elements iron and aluminium in the surface ocean using a towed Fish coupled to flow injection analysis, Deep-Sea Res. Pt. I, 47, 1141-1156, 2000.

Walmsley, J. and Kennedy, C.: Temperature-Dependent Regulation by Molybdenum and Vanadium of Expression of the Structural Genes Encoding Three Nitrogenases in Azotobactervinelandii, Appl. Environ. Microb., 57(2), 622-624, 1991.
Webb, E. A., Moffett, J. W., and Wasterbury, J. B.: Iron Stress in Open-Ocean Cyanobacteria (Synechococcus, Trichodesmium, and Crocosphaera spp.): Identification of the IdiA Protein, Appl. Environ. Microb., 67(12), 5444-5452, 2001.

Westberry, T. K. and Siegel, D. A.: Spatial and temporal distribution of Trichodesmium blooms in the world's oceans, Global Biogeochem. Cy., 20(4), GB4016, doi:10.1029/2005GB002673, 2006.

Whitfield, M.: Interactions between phytoplankton and trace metals in the open ocean, Adv. Mar. Biol., 41, 1-128, 2001.

Winter, J. M. and Moore, B. S. J.: Exploring the Chemistry and Biology of Vanadium-dependent Haloperoxidases, J. Biol. Chem., 284, 18577-18581, 2009.

Zehr, J. P., Harris, D., Dominic, B., and Salerno, J.: Structural analysis of the Trichodesmium nitrogenase iron protein: implications for aerobic nitrogen fixation activity, FEMS Microbiol. Lett., 153, 303-309, 1997. 